Review

\title{
Vaccines against COVID-19: Priority to mRNA-Based Formulations
}

\author{
Steve Pascolo $\mathbb{D}$
}

check for updates

Citation: Pascolo, S. Vaccines against COVID-19: Priority to mRNA-Based Formulations. Cells 2021, 10, 2716. https://doi.org/10.3390/cells10102716

Academic Editor: Arnaldo Caruso

Received: 25 August 2021

Accepted: 8 October 2021

Published: 11 October 2021

Publisher's Note: MDPI stays neutral with regard to jurisdictional claims in published maps and institutional affiliations.

Copyright: (C) 2021 by the author. Licensee MDPI, Basel, Switzerland. This article is an open access article distributed under the terms and conditions of the Creative Commons Attribution (CC BY) license (https:/ / creativecommons.org/licenses/by/ $4.0 /)$.
Department of Dermatology, University Hospital of Zürich, Raemistrasse 100, 8091 Zürich, Switzerland; steve.pascolo@usz.ch

\begin{abstract}
As of September 2021, twenty-one anti-COVID-19 vaccines have been approved in the world. Their utilization will expedite an end to the current pandemic. Besides the usual vaccine formats that include inactivated viruses (eight approved vaccines) and protein-based vaccines (four approved vaccines), three new formats have been validated: recombinant adenovirus (six approved vaccines), plasmid DNA (one approved vaccine), and messenger RNA (mRNA, two approved vaccines). The latter was the fastest (authorized in 2020 in the EU, the USA, and Switzerland). Most Western countries have reserved or use the protein vaccines, the adenovirus vaccines, and mRNA vaccines. I describe here the different vaccine formats in the context of COVID-19, detail the three formats that are chiefly reserved or used in Europe, Canada, and the USA, and discuss why the mRNA vaccines appear to be the superior format.
\end{abstract}

Keywords: mRNA; protein; adenovirus; SARS-CoV-2; vaccine; spike

\section{Introduction}

Since the validation by Jenner of the principle of vaccination (using cow- ("vacca") pox virus as a prophylaxis for smallpox), attenuated and inactivated viruses have been the components of efficacious vaccines. Their production, which requires usually animal cells (or eggs), can be difficult (particularly if the virus is lytic), and their purification cannot be too stringent as it would destroy their integrity. As a consequence, the vaccines based on whole viruses contain impurities from the production process that may cause problems, in terms of the induction of irrelevant immunity and intolerance/allergies. Subunit vaccines have proven to be safe and efficacious and somewhat easier to produce, purify, and store. They, however, must be complemented with adjuvants. More recently, recombinant attenuated viruses have been generated that rely on robust production, safety, and efficacy features established for modified attenuated viruses (for example, adenoviruses). This type of vaccine was first approved in summer 2020 for protection against Ebola https: / / johnsonandjohnson.gcs-web.com/static-files /1c979f4f-cad3-4f8b-9a22-69aaac503570 (accessed on 7 October 2021). Finally, since the end of the 1990s, companies (starting with the one I cofounded: CureVac) are developing vaccines based on synthetic, in vitro-transcribed mRNA (ivt mRNA) [1-5]. This format, first published by a French team in 1993 [6], confirmed later by an American team [7] and a German team [8], was originally neglected because mRNA was believed to be a fragile molecule. This is a misconception. Because of the omnipresence of RNases, research and development with mRNA must be conducted in special "RNase-free" conditions. However, the mRNA molecules themselves are physiochemically very stable in the absence of RNases and at neutral to acidic $\mathrm{pH}$ (to avoid deprotonation of the $2^{\prime} \mathrm{OH}$, which could result in ester cleavage of the RNA backbone). They can be frozen, thawed, lyophilized, and resuspended without losing any functionality [1]. As a matter of fact, mRNA is the only biological macromolecule that can be heated up to $95{ }^{\circ} \mathrm{C}$ without losing its activity [5]. Other biological macromolecules such as DNA, proteins, or also viruses lose their functionality if they are heated up to the same high temperatures (even if, in controlled laboratory conditions, proper 
refolding of proteins or annealing of DNA strands could take place after denaturation using precisely established cooling methods). Thus, counterintuitively, mRNA is the most stable biological molecule for the production of vaccines (the liposomes used to generate mRNA vaccines may not be stable; that is why the current mRNA vaccines have to be stored at low temperatures). The European Union has recognized this feature by awarding CureVac, in 2014, a two-million Euro prize for vaccines stable at room temperature (https:/ / ec.europa.eu/commission/presscorner/detail/en/IP_14_229 accessed on 7 October 2021). Still, the prejudice that mRNA would be instable remained strongly present in the psyche of the scientific and medical communities, which plagued the development of mRNA-based drugs for the last thirty years. The COVID-19 pandemic created a definitive U-turn in this bias and allowed the mRNA vaccine to showcase its potential (i.e., its speed/ease of production, safety, and efficacy), which made it the first vaccine format approved against SARS-CoV-2 infections, less than one year after the publication of the viral sequence [9]. After this tour-de-force, some recombinant attenuated adenovirus, inactivated SARS-CoV-2, plasmid- and protein-based anti-SARS-CoV-2 vaccines have also been approved, and this gives the world currently a panel of 21 prophylactic weapons against the pandemic (https: / / covid19.trackvaccines.org/vaccines/ accessed on 7 October 2021).

\section{Are All Anti-COVID-19 Vaccines Similar in Their Safety and Efficacy Profile?}

Concerning safety, as they all passed the evaluation processes, they all have been approved as safe (even if, as expected for vaccines, side effects have been recorded, such as frequent fatigue and local reactogenicity; rare allergies could be observed). However, are there also theoretical concerns that should be mentioned?

Concerning efficacy, all approved vaccines protect well against COVID-19 (more than $70 \%$, which is higher than most flu vaccines, and some up to over $95 \%$ ). Although all current recombinant vaccines use the SARS-CoV-2 spike protein as a target, some use the wild-type protein (for example, AstraZeneca's adenovirus vaccine), while others use a mutated version of it (for example, the vaccines from Moderna and BioNTech/Pfizer), in particular one that contains two consecutive prolines (lysine 986 and valine 987 are both replaced with prolines: "PP Spike"). This was previously shown for the SARS-CoV and MERS-CoV spikes to keep the protein in a prefusion conformation (the conformation at the virus surface) [10].

\section{Anti-COVID-19 Vaccines}

Five vaccine platforms are currently providing approved vaccines against SARS-CoV-2:

1. Vaccines based on ivt mRNA developed primarily in Europe and the U.S. by BioNTech/Pfizer and Moderna;

2. Vaccines based on recombinant deficient adenoviruses optimized and produced in different countries and by companies including AstraZeneca, Johnson \& Johnson/Janssen, and CanSino;

3. Protein-based vaccines mostly advanced in the U.S. and Russia;

4. Inactivated SARS-CoV-2 viruses developed mostly in China and India;

5. A plasmid DNA vaccine only approved in India.

In addition, promising new experimental vaccination approaches such as, for example, aerosolized adenovirus [11], adeno-associated viral (AAV)-based vaccines [12], live attenuated vaccines that can be applied intranasally $[13,14]$, or other vector vaccines such as modified vaccinia virus Ankara (MVA)-based approaches [15] are being developed. However, they will not be further detailed here. Meanwhile, little information is available about inactivated SARS-CoV-2 and plasmid DNA. Thus, I will present in the following the features of the three platforms (ivt mRNA, recombinant adenovirus, and purified protein) for which most Western countries have reserved millions of doses. Table 1 presents the advantages and disadvantages (in some cases, only theoretical) of the most used platforms, and Table 2 presents the results obtained against COVID-19. 
Table 1. Advantages and disadvantages of selected vaccine platforms.

\begin{tabular}{ccccc}
\hline & Design & Upscaling & $\begin{array}{c}\text { Re-Using Established } \\
\text { GMP Conditions }\end{array}$ & $\begin{array}{c}\text { Theoretical Safety } \\
\text { Concerns }\end{array}$ \\
\hline $\begin{array}{c}\text { Recombinant viral } \\
\text { vector (adenovirus) }\end{array}$ & Not easy & To be optimized & Not guaranteed & $\begin{array}{c}\text { Recombination/ } \\
\text { persistence/integration }\end{array}$ \\
\hline $\begin{array}{c}\text { ivt mRNA } \\
\begin{array}{c}\text { Proteins/ } \\
\text { sugars }\end{array}\end{array}$ & Easy & Easy & Guaranteed & None \\
\hline Inactivated viruses & Eot easy & To be optimized & Not guaranteed & None \\
\hline
\end{tabular}

Table 2. Vaccines against COVID-19 chiefly ordered by Westernized countries.

\begin{tabular}{|c|c|c|c|c|c|c|}
\hline Platform & Company & Spike * & $\begin{array}{c}\text { Efficacy } \\
\text { (January 2020 } \\
\text { SARS-CoV-2) }\end{array}$ & $\begin{array}{l}\text { Efficacy (Beta } \\
\text { Variant }{ }^{\&} \text { ) }\end{array}$ & Dosing & $\begin{array}{c}\text { Theoretical } \\
\text { Concerns }\end{array}$ \\
\hline \multirow[t]{2}{*}{ Purified protein } & Novavax \# & PP & $95 \%$ & Reduced & $\begin{array}{c}5 \mu \mathrm{g} 2 \times \text { with } \\
\text { 3-week interval }\end{array}$ & \multirow{2}{*}{$\begin{array}{c}\text { Induction of } \\
\text { immunity agains } \\
\text { contaminants }\end{array}$} \\
\hline & Sanofi-GSK \# & PP & Not yet known & Not yet known & Undisclosed & \\
\hline \multirow{2}{*}{$\begin{array}{l}\text { Recombinant } \\
\text { adenovirus }\end{array}$} & AstraZeneca & WT & $\begin{array}{c}\text { Between } 62 \% \\
\text { and } 90 \%\end{array}$ & $\begin{array}{l}\text { Strongly } \\
\text { reduced }\end{array}$ & $\begin{array}{l}\text { ca. } 2 \mu \mathrm{g} 2 \times \text { with } \\
\text { 4-week interval }\end{array}$ & \multirow{2}{*}{$\begin{array}{l}\text { Recombination } \\
\text { Integration } \\
\text { in genome }\end{array}$} \\
\hline & $\mathrm{J} \& \mathrm{~J} / \mathrm{Janssen}$ & PP & $72 \%$ & Not reduced & ca. $2 \mu \mathrm{g}$ once & \\
\hline \multirow{3}{*}{ ivt mRNA } & $\begin{array}{l}\text { BioNTech } \\
\text { /Pfizer }\end{array}$ & PP & $95 \%$ & $\begin{array}{l}\text { Slightly } \\
\text { reduced }\end{array}$ & $\begin{array}{c}30 \mu \mathrm{g} 2 \times \text { with } \\
\text { 3-week interval }\end{array}$ & \multirow{3}{*}{ None } \\
\hline & CureVac \# & PP & $47 \%{ }^{\$}$ & Not yet known & $\begin{array}{l}12 \mu \mathrm{g} 2 \times \text { with } \\
\text { 4-week interval }\end{array}$ & \\
\hline & Moderna & PP & $94.1 \%$ & $\begin{array}{l}\text { Slightly } \\
\text { reduced }\end{array}$ & $\begin{array}{l}100 \mu \mathrm{g} 2 \times \text { with } \\
\text { 4-week interval }\end{array}$ & \\
\hline
\end{tabular}

* Either the wild-type sequence of the ARS-CoV-2 spike (WT) or the modified sequence containing two consecutive prolines (PP) is used.

$\$$ The CureVac vaccine was tested later than the others and, as a consequence, in the context of numerous variants. \# Vaccine not yet approved. \& Data for all variants of concern are not yet available for each vaccine; thus, the description is limited here to the beta variant.

\section{Protein-Based Vaccines}

A safety advantage of proteins is that they are inert and naturally eliminated. However, when produced in cell culture, they contain contaminants coming from the cultures [16]. This must be kept in mind particularly when allergic patients are vaccinated. In addition, protein-based vaccines require an adjuvant. The design and production of a protein for a vaccine can be somewhat cumbersome as every protein is different (by its structure and glycosylation status and whether it is hydrophilic or hydrophobic). Thus, obtaining and preserving the correct antigenic features of the purified protein in the vaccine can be a challenge. Should the vaccine contain immunogenic impurities (including misfolded antigens), it could induce an irrelevant immune response. The protein vaccine from Novavax contains a recombinant full-length SARS-CoV-2 PP spike (also mutated in positions 682 to 685 in order to confer protease resistance) that is produced in insect cells and mixed with Matrix-M1, a saponin-based adjuvant. It is stored at $2{ }^{\circ} \mathrm{C}$ to $8{ }^{\circ} \mathrm{C}$. The tested doses were $5 \mu \mathrm{g}$ and $25 \mu \mathrm{g}$ of protein per injection and were found to induce similar high titers of neutralizing antibodies in phase I trials [17]. The phase III trial was performed with two injections of $5 \mu \mathrm{g}$ SARS-CoV-2 rS + $50 \mu \mathrm{g}$ Matrix-M1 adjuvant $21 \mathrm{~d}$ apart. The company reported in January 2021 an 89.3\% efficacy against COVID-19 (95.6\% against the original COVID-19 strain and 85.6\% against the alpha variant strain B.1.1.7 identified in the U.K.). Those data are confirmed in a recent publication: efficacy of $86.3 \%$ against the alpha variant and $96.4 \%$ against non-alpha variants [18]. Thus, the Novavax vaccine appears as an efficient and safe product of great interest. Another protein vac- 
cine (EpiVacCorona) is available and approved in Russia. However, little information is available (https: / / clinicaltrials.gov/ct2/show / NCT04527575 accessed on 7 October2021). Nevertheless, it could be of interest as it is not produced by cells, but chemically synthesized. The chemical peptide antigens corresponding to the SARS-CoV-2 protein are conjugated to a carrier protein and adsorbed on an aluminum hydroxide. These types of chemically synthesized vaccines would not contain contaminants such as proteins from the producing cells in vitro and therefore may present less risk of inducing allergies or irrelevant immunity.

\section{Adenovirus-Based Vaccines}

Adenoviruses are nonenveloped viruses that are particularly resistant to chemical or physical agents. Replication-defective adenoviruses are used to generate recombinant vaccines [19]. The recombinant DNA contained in these viruses is actively sent to the nucleus of mammalian cells, where it can be transcribed into mRNA. Usually, vaccine adenoviruses are deleted of the early gene E1 so that they can infect cells, but not replicate. Their production is possible thanks to complementation in cells that express E1. The AstraZeneca vaccine is produced in HEK293 cell lines that are derived from human embryonic kidney cells (taken from an aborted female fetus in 1973) transformed by integration of a part of adenovirus 5 that also gives the expression of the E1 proteins. Thanks to this protein, HEK293 can produce viruses that are deficient for E1. The gene coding for the antigen (here, the SARS-CoV-2 spike) is introduced into these replication-deficient viruses, rendering them into recombinant replication-defective (thereby attenuated) vaccine viruses. The production of adenoviruses requires cell culture and optimization of this process. Theoretical concerns include whether the recombinant defective adenovirus could recombine/evolve in vitro during production (not all viruses collected from cell culture would have the same sequences) or in vivo after injection (for example, in a person being infected with a common adenovirus), leading to the production of new adenoviruses. Another concern is the persistence and integration of the chimeric DNA in the human genome. DNA viruses are known to eventually integrate into one out of one million cells in vivo in mice for adenoviruses [20]. In addition, it is not known how the DNA sequence of the SARS-CoV-2 spike (which normally does not exist in nature since coronaviruses are RNA viruses) would behave in cells and whether it could influence persistence and integration rates (one could speculate by sheer unfortunate chance that the SARS-CoV-2 spike DNA sequence could be stabilized by peculiar DNA-specific proteins such as special histones or by DNA recombination machineries; however, so far, no evidence supporting this theory has been reported). The recombinant adenoviruses combine several elements from several viruses that would not have met in nature, and the long-term outcome in vivo of such chimeras is still to be determined.

Among the approved adenovirus-based vaccines, the one primarily utilized and most widely distributed so far is from AstraZeneca and named ChAdOx1 nCoV-19 (AZD1222). It is a recombinant replication-deficient chimpanzee adenovirus in which a promoter from cytomegalovirus was introduced before a gene sequence from the tissue plasminogen activator (the leader sequence); it also contains the cDNA coding for the full-length wildtype spike and, at the end, a bovine growth hormone polyadenylation sequence. The vaccine $\left(5 \times 10^{10}\right.$ particles per injection, which means approximately $1.5 \mu \mathrm{g}$ of DNA) is administered intramuscularly in two doses, given between $4 \mathrm{wk}$ and $12 \mathrm{wk}$ apart. It was reported to give a different level of protection (depending on the dose and the clinical trial center), but the overall efficacy was above $70 \%$ [21]. Although it protects against the alpha variant, it does not seem to protect well against the beta variant (B.1.351 identified in South Africa) [22]. Several countries (including Denmark, Austria, Estonia, Latvia, and Luxemburg) have suspended vaccination with ChAdOx1 nCoV-19 because of cases of thrombosis seen after vaccination. The link between the vaccine and these symptoms has been established [23]. Another attenuated recombinant adenovirus that is broadly approved as a vaccine against SARS-CoV-2 is Sputnik V (Gamaleya Research Institute), 
developed in Russia. It consists of two replication-deficient adenoviruses (recombinant adenovirus type 26 and recombinant adenovirus type 5 , given sequentially), both of which carry the gene for the full-length wild-type spike (rAd26-S and rAd5-S). The vaccine is administered at a dose of $10^{11}$ particles intramuscularly in two doses $21 \mathrm{~d}$ apart and provides $91.6 \%$ efficacy [24]. Meanwhile, the approved Johnson \& Johnson/Janssen recombinant adenovirus vaccine Ad26.COV2.S was selected among seven experimental recombinant adenovirus serotype 26 (Ad26) vector-based vaccines. It notably also differs from the AstraZeneca vaccine because it encodes for a spike that has the two prolines stabilizing the prefusion conformation. A single intramuscular shot of $5 \times 10^{10}$ particles provided $66 \%$ protection against moderate and severe COVID-19 even in South Africa, where the (beta) B.1.351 variant is prevalent [25] (https:/ / www.fda.gov/media/146265/download accessed on 7 October 2021).

\section{Nonreplicating ivt mRNA Vaccines}

The main feature of nonreplicating ivt mRNA vaccines is their safety. Indeed, this natural molecule cannot replicate, is active in the cytosol, and is quickly and fully degraded by abundant RNases. Thus, as opposed to recombinant adenoviruses or plasmid DNA, but similar to proteins, this vaccine format has no risk to persist, recombine, or modify the host genome [1-4]. As we have shown in our 2006-certified first worldwide pharmaceutical production plant in Tuebingen, Germany, synthetic mRNA can be easily produced at large scales and highly purified by HPLC [5]. Indeed, following on from the project imagined by Prof. Rammensee in Tuebingen in 1996 and executed mostly by Dr. Ingmar Hoerr (as part of his Ph.D. training) [8], I started testing and optimizing synthetic mRNA vaccines in 1998 (at that time, I was a postdoctoral researcher in Prof. Rammensee's laboratory) in wild-type and humanized mice (HHD) that I developed during my Ph.D. at the Pasteur Institute in France $[26,27]$. Initial experiments indicated that this format works as an anticancer vaccine and antiviral vaccine; however, immune responses were usually weaker than those induced by other vaccine formats, for example plasmid DNA. The safety advantage of mRNA (being quickly degraded) stimulated us to further optimize this format with the goal of bringing it to the clinic. To this end, we studied the parameters that are important for optimizing the mRNA vaccine (i.e., stability of the mRNA [28], expression of the encoded protein [29], HPLC purification [1], formulation [30], and immunostimulating capacities of RNA [31,32]) and, as a result, implemented the first worldwide pharmaceutical manufacturing of synthetic in vitro transcribed (ivt) mRNA [1]. Starting in 2003, we also conducted, with the Dermatology and Haemato-oncology Departments of Tuebingen's University Hospital, the first studies in man, evaluating the expression of synthetic mRNA injected in my own skin (Figure 1) [29], and the safety and efficacy of anticancer vaccines based on synthetic mRNA [33-35].

Improvements of the ivt mRNA production, design, and structure these last $20 \mathrm{y}$ have transformed this molecule into a very efficient genetic vehicle for vaccines and therapies $[36,37]$. Of note, a revolutionary Cap analog named CleanCap has largely improved the production and efficacy of synthetic mRNA [38]. The ivt mRNA encodes a single antigen, limiting the risk of triggering immunity against irrelevant antigens, as can be seen with proteins (i.e., contaminants, misfolded proteins) or adenoviruses (vector proteins). The synthetic mRNA used in the anti-COVID-19 vaccines is condensed in liposomes consisting usually of four different lipids and related to the other RNA (not an mRNA, but a small inhibitory RNA, siRNA) liposomal formulation approved in 2018: ONPATTRO (injected intravenous at $30 \mathrm{mg}$ per dose intravenous every $3 \mathrm{wk}$ for the treatment of polyneuropathy, caused by hereditary transthyretin-mediated amyloidosis). One of the qualities of the ivt mRNA vaccine is the speed and ease of production: any DNA sequence preceded by an adequate promoter (usually from the T7 or SP6 bacteriophages) is efficiently transcribed in vitro using the recombinant RNA polymerase (usually T7 or SP6 [39]) [5]. One molecule of DNA can give over one-thousand molecules of mRNA within a few hours. The production of mRNA required for one million doses of an ivt mRNA vaccine can be achieved in $6 \mathrm{~L}$ of in vitro transcription, while the production of viruses for one million vaccine 
doses typically requires $6000 \mathrm{~L}$ of cell culture [5]. All products in the transcription reaction (DNA, RNA polymerase, nucleotides, Cap analog) are from bacteria or chemical origins. Thus, the ivt mRNA vaccine is "vegan". Besides overcoming religious or behavior limits, this feature also reduces the risk of allergies or the development of irrelevant immunity against contaminants from cell cultures. As we discovered in early 2000, RNA is a danger signal that triggers Toll-like receptors $[31,32,40]$. Thus, (unmodified) mRNA-based vaccines contain an intrinsic adjuvant. The induction of inflammation is required to trigger the development of an immune response after injection of a formulation.

A

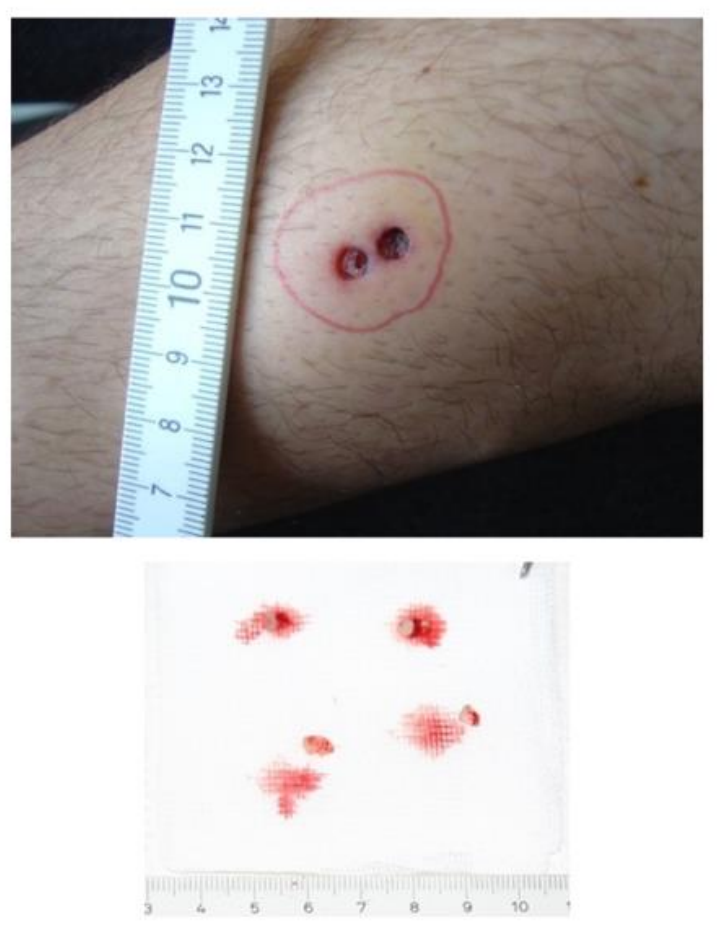

B

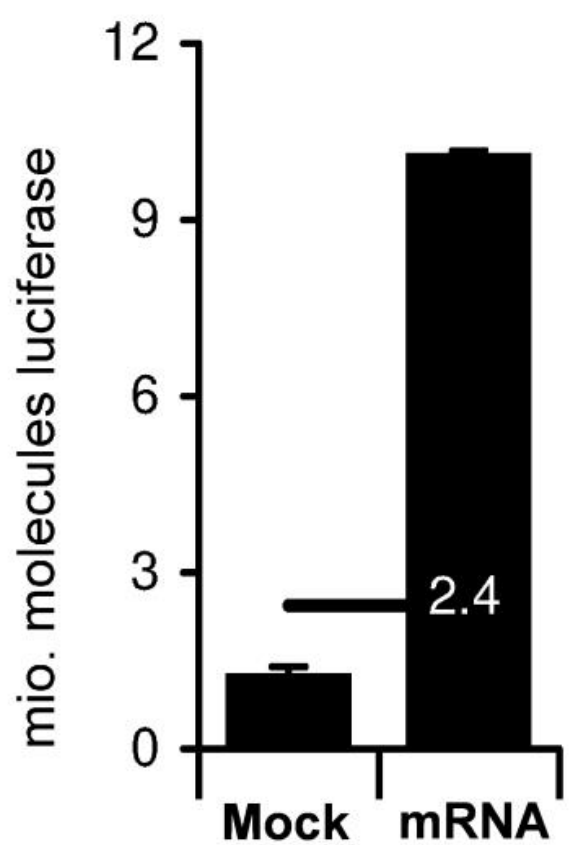

Figure 1. The first injection of ivt mRNA coding luciferase in human skin as published in 2007 [29]. In A, upper panel, the area of my skin, which was the site of intradermal administration of $120 \mu \mathrm{g}$ of unmodified synthetic mRNA coding for luciferase, is circled in red (evident by the bubble formed by the intradermal injection). Seventeen hours later, under local anesthesia, three-millimeter punch biopsies (lower panel) were taken in (as seen in the upper panel) and outside (not shown) the mRNA injection site, as well as in PBS ("Mock") injected sites. The skin is not inflamed, and there were no systemic side effects, showing that injection of unmodified synthetic mRNA is safe in humans. The measurement of luciferase activity in these biopsies (A, lower panel), as well as in other biopsies taken from other sites of my skin distant from the site of mRNA injection ("Mock") demonstrated that naked synthetic mRNA could be taken up and expressed locally in human skin (in B; data similar to what we published previously [5]). The experiment was repeated three times between 2003 and 2005. Only biopsies within the area receiving mRNA (delimited in red) were emitting luminescence above background levels in the presence of luciferin substrate. These results demonstrated that the data generated in mice (the surprising uptake and expression of injected naked ivt mRNA) is not restricted to this organism, but can be extended to humans. As written in the article reporting these results in 2007, "A qualified healthy individual volunteered for intradermal injections of $150 \mu \mathrm{L}$ of a Ringer lactate solution containing the GMP quality RNActive coding for luciferase. Before performing the experiment, a letter of consent was signed by the volunteer.". The injections, anesthesias, and punch biopsies were performed by a medical doctor in the Dermatology Department at the University Clinic of Tuebingen and according to German regulations.

Although the utilization of synthetic mRNA in vaccines is relatively new (described first in 1993 [6], injected in patients [33-35] and myself (Figure 1) [29] in the mid-2000s, and approved first in 2020 [9]), the utilization of natural mRNA to vaccinate is ancient: the yellow fever, mumps, measles, and rubella vaccines are attenuated RNA viruses that 
immunize after subcutaneous injection, by delivering their mRNA into the host cells, which subsequently produce viral particles that initiate an immune response. These ancient vaccines can therefore be considered "natural" mRNA vaccines, while the newly approved anti-SARS-CoV-2 vaccines are "synthetic" mRNA vaccines. However, they both rely on the same fundamental mechanisms: the production of viral proteins by host cells using injected mRNA. The optimization of the ivt mRNA molecules and of the liposomal formulations have turned the ivt mRNA vaccine into a very potent format [37,41]. It has been largely evaluated in clinical trials mostly as a vaccine against cancer [42,43]. However, it has not yet demonstrated efficacy in cancer treatment as a pivotal study in prostate carcinoma by CureVac did not demonstrate a survival advantage in vaccinated patients. Meanwhile, BioNTech together with Genentech is currently performing a phase II study with an individualized unmodified mRNA vaccine coding for mutations identified in tumor biopsies. Each patient receives his/her own tailored vaccine (http:/ / merit-consortium.eu/ accessed on 7 October 2021). Thus, it can be expected that anticancer mRNA vaccines, particularly when used in combination with other treatments (chemotherapy, radiotherapy, immunotherapy), will soon be approved.

In the context of COVID-19, in the first half of 2020, five nonreplicating mRNA vaccines were produced and evaluated: three by BioNTech (BNT162a1, which is made with unmodified nucleotides; BNT162b1 [44-46] and BNT162b2 [9], which contain pseudo-uridine, the " 1 " series coding for the receptor binding domain of spike, while the " 2 " codes for the full-length spike), one by CureVac ( $\mathrm{CvNCoV}$, which is made with unmodified nucleotides and codes the full-length spike [47] (preprint at https: / papers.ssrn.com/sol3/papers.cfm? abstract_id=3911826 accessed on 7 October 2021), and one by Moderna (which contains pseudo-uridine and codes the full-length spike [48]). The results obtained in humans with the unmodified mRNA vaccine BNT162a1 are not yet published. Originally, the pseudouridine modification was coined in 2005 to abrogate innate immunostimulation by RNA (triggering of Toll-like receptors) [49], allowing the use of ivt mRNA for nonimmunogenic (nonvaccinal) expression of protein. However, it was published in 2017 that, surprisingly, even modified mRNA can be used in mRNA vaccines [50]. The adjuvant effects in this case probably come from the lipids used in the liposomal formulations (the liposomes are similar in BioNTech/Pfizer, CureVac, and Moderna, although small variations in some of the lipids characterize each of them as presented in the review [36]). Whether modified (pseudo-uridine) or unmodified mRNA is better for an ivt mRNA vaccine is not yet established and may largely depend on formulation, dose, site of injection and intended aim (e.g., induction of antibodies and/or T-cells; targeting infectious agents, allergies or cancers). Injections of unmodified RNA induces production of type I interferon (stimulation of, e.g., TLR7) that may induce the blockade of the translation and degradation of mRNA. On this basis, it is proposed that modified mRNA would trigger a better adaptive immune response thanks to a higher translation and stability of the foreign mRNA. However, two parameters would argue against this hypothesis: (i) not all cells respond to type I interferon, and the immune system has developed specialized antigen-presenting cells (characterized by the expression of USP18) that maintain protein translation even in the presence of type I interferons, in order to further stimulate lymphocytes in the context of an infection [51]; (ii) type I interferon was reported to be important for effective and long-lived adaptive immunity (review in [37]). Thus, it remains to be determined whether for the induction of the most efficient and long-lived anti-COVID-19 immunity, an unmodified or a modified mRNA should be used in the vaccine formulations.

Although the first injections of an anti-SARS-CoV-2 ivt mRNA vaccine (and the first worldwide injection in humans of an experimental anti-SARS-CoV-2 vaccine) in volunteers was conducted by Moderna on March 16 2020, the first approval was for the mRNA vaccine of BioNTech in association with Pfizer $\left(\right.$ Comirnaty $^{\circledR}$ ) in December 2020. These two mRNA vaccines give over $90 \%$ protection against COVID-19 $[9,48]$ and protect against emerging variants (although the neutralization of the beta variant requires lower dilutions of sera than those required to neutralize the initial virus and other variants) [52]. CureVac's 
unmodified mRNA vaccine gives an efficacy of $48.2 \%$ against symptomatic COVID-19 but interestingly an efficacy of 70.7\% against moderate-to-severe COVID-19 (preprint at https: / / papers.ssrn.com/sol3/papers.cfm?abstract_id=3911826 accessed on 7 October 2021). In the age group of 18 to 60, protection against moderate-to-severe disease was calculated to be $77 \%$. The company seeks regulatory approval in the segment of the population where it provides protection (https: / / www.curevac.com/en/2021/08/31/curevacs-cvncov-phase2b-3-study-data-published-in-preprints-with-the-lancet/ accessed on 7 October 2021).

In Israel, where a majority of the population has been vaccinated using the BioNTech/Pfizer or Moderna vaccine, a study on over 1,000,000 persons (596,618 vaccinated and 596,618 nonvaccinated) demonstrated a vaccine efficacy of $92 \%$ against infection, $94 \%$ against symptomatic COVID-19, 87\% against hospitalization, and 92\% against severe disease (determined $7 \mathrm{~d}$ or more after the second dose). Thus, the approved mRNA vaccines are highly efficacious, not only in preventing the disease, but also transmission [53].

Thanks to the upgraded production capacities of BioNTech and Moderna (the implementation of new and large mRNA production factories: in Visp, Switzerland, for Moderna-in collaboration with Lonza-and Marburg, Germany for BioNTech.), it is expected that there will be enough synthetic mRNA vaccine doses to fully, safely, and efficiently vaccinate a large part of the Western world's population before the end of 2021.

\section{Conclusions}

Although, as expected for vaccines that strongly activate the immune system, the approved vaccines against SARS-CoV-2 have frequent side effects (mostly fatigue, headaches, and local reactogenicity), they all provide efficient protection against COVID-19 and are widely administered in order to end the pandemic. Four vaccine formats are largely approved in the world. The ivt mRNA vaccine combines the safety aspects of the traditional inactivated virus- and protein-based vaccines (inert and quickly eliminated), while it has the versatility of recombinant viruses. However, as opposed to recombinant adenoviruses, ivt mRNA-based vaccines do not have the risk of evolving, recombining, or integrating in genomes, and as opposed to proteins or inactivated viruses, the risk of inducing immunity against contaminants is limited. The safety and flexibility aspects of the ivt mRNA vaccines have turned them into the winners of the race to develop vaccines against COVID-19. These features also keep this format optimal in terms of the design and production of vaccines that might be needed in case variants of SARS-CoV-2 resisting the current vaccine-induced immune response emerge (this is so far not the case even if the beta variant is less well recognized than other variants by mRNA-vaccine-induced antibodies). As the vaccines induced immune response declines over time [54], a third dose more than six months after the second dose is recommended, particularly in elderly people or at-risk groups. In Israel, although a fourth wave of COVID came in summer 2021, it is estimated that, altogether, two thirds of hospitalizations and deaths have been prevented by the mRNA vaccine campaign [55]. This illustrates the great benefits brought by the anti-COVID mRNA vaccines. Thanks to their safety and ease of production, mRNA vaccines, as well as mRNA-based therapies are being intensively developed with the promise to create new drugs against many different diseases.

Funding: This work was funded by the University of Zurich (URPP “Translational Cancer Research), the department of Dermatology at the University Hospital of Zurich, the "Stiftung für wissenschaftliche Forschung an der Universität Zürich", the Swiss National Science Found NRP 78 program, grant number 4078PO_198321 and the EU grant NEWmRNA (Horizon 2020 research and innovation programme No. 965135).

Conflicts of Interest: Steve Pascolo cofounded CureVac in 2000, but left the company and separated from his shares in 2006. He has no shares nor participation in any mRNA company (BioNTech, Moderna, or CureVac). He works in collaboration with BioNTech in the context of RNA-based anticancer therapies (EU grant MERIT 2012: http:/ / merit-consortium.eu/). 


\section{References}

1. Pascolo, S. Messenger RNA-based vaccines. Expert Opin. Biol. Ther. 2004, 4, 1285-1294. [CrossRef] [PubMed]

2. Pascolo, S. Vaccination with messenger RNA. DNA Vaccines 2006, 127, 23-40. [CrossRef]

3. Pascolo, S. Vaccination with messenger RNA (mRNA). In Toll-Like Receptors (TLRs) and Innate Immunity. Handbook of Experimental Pharmacology; Bauer, S., Hartmann, G., Eds.; Springer: Berlin/Heidelberg, Germany, 2008; Volume 183, pp. 221-235. [CrossRef]

4. Pascolo, S. The messenger's great message for vaccination. Expert Rev. Vaccines 2015, 14, 153-156. [CrossRef] [PubMed]

5. Pascolo, S. Messenger RNA: The inexpensive biopharmaceutical. J. Multidiscip. Eng. Sci. Technol. 2017, 4, 6937-6941.

6. Martinon, F.; Krishnan, S.; Lenzen, G.; Magné, R.; Gomard, E.; Guillet, J.-G.; Lévy, J.-P.; Meulien, P. Induction of virus-specific cytotoxic T lymphocytesin vivo by liposome-entrapped mRNA. Eur. J. Immunol. 1993, 23, 1719-1722. [CrossRef]

7. Conry, R.M.; LoBuglio, A.F.; Wright, M.; Sumerel, L.; Pike, M.J.; Johanning, F.; Benjamin, R.; Lu, D.; Curiel, D.T. Characterization of a messenger RNA polynucleotide vaccine vector. Cancer Res. 1995, 55, 1397-1400.

8. Hoerr, I.; Obst, R.; Rammensee, H.G.; Jung, G. In vivo application of RNA leads to induction of specific cytotoxic T lymphocytes and antibodies. Eur. J. Immunol. 2000, 30, 1-7. [CrossRef]

9. Polack, F.P.; Thomas, S.J.; Kitchin, N.; Absalon, J.; Gurtman, A.; Lockhart, S.; Perez, J.L.; Marc, G.P.; Moreira, E.D.; Zerbini, C.; et al. Safety and efficacy of the BNT162b2 mRNA Covid-19 vaccine. N. Engl. J. Med. 2020, 383, 2603-2615. [CrossRef]

10. Pallesen, J.; Wang, N.; Corbett, K.S.; Wrapp, D.; Kirchdoerfer, R.N.; Turner, H.L.; Cottrell, C.A.; Becker, M.M.; Wang, L.; Shi, W.; et al. Immunogenicity and structures of a rationally designed prefusion MERS-CoV spike antigen. Proc. Natl. Acad. Sci. USA 2017, 114, E7348-E7357. [CrossRef]

11. Wu, S.; Huang, J.; Zhang, Z.; Wu, J.; Zhang, J.; Hu, H.; Zhu, T.; Zhang, J.; Luo, L.; Fan, P.; et al. Safety, tolerability, and immunogenicity of an aerosolised adenovirus type-5 vector-based COVID-19 vaccine (Ad5-nCoV) in adults: Preliminary report of an open-label and randomised phase 1 clinical trial. Lancet Infect. Dis. 2021, 10. Online ahead of print. [CrossRef]

12. Zabaleta, N.; Dai, W.; Bhatt, U.; Hérate, C.; Maisonnasse, P.; Chichester, J.A.; Sanmiguel, J.; Estelien, R.; Michalson, K.T.; Diop, C.; et al. An AAV-based, room-temperature stable, single dose COVID-19 vaccine provides durable immunogenicity and protection in non-human primates. Cell Host Microbe 2021, 29, 1437-1453.e8. [CrossRef]

13. Trimpert, J.; Dietert, K.; Firsching, T.C.; Ebert, N.; Thao, T.T.N.; Vladimirova, D.; Kaufer, S.; Labroussaa, F.; Abdelgawad, A.; Conradie, A.; et al. Development of safe and highly protective live-attenuated SARS-CoV-2 vaccine candidates by genome recoding. Cell Rep. 2021, 36, 109493. [CrossRef]

14. Wang, Y.; Yang, C.; Song, Y.; Coleman, J.R.; Stawowczyk, M.; Tafrova, J.; Tasker, S.; Boltz, D.; Baker, R.; Garcia, L.; et al. Scalable live-attenuated SARS-CoV-2 vaccine candidate demonstrates preclinical safety and efficacy. Proc. Natl. Acad. Sci. USA 2021, 118, e2102775118. [CrossRef]

15. Tscherne, A.; Schwarz, J.H.; Rohde, C.; Kupke, A.; Kalodimou, G.; Limpinsel, L.; Okba, N.M.A.; Bošnjak, B.; Sandrock, I.; Odak, I.; et al. Immunogenicity and efficacy of the COVID-19 candidate vector vaccine MVA-SARS-2-S in preclinical vaccination. bioRxiv 2021, 118, e2026207118. [CrossRef]

16. Dertzbaugh, M.T. Genetically engineered vaccines: An overview. Plasmid 1998, 39, 100-113. [CrossRef] [PubMed]

17. Keech, C.; Albert, G.; Cho, I.; Robertson, A.; Reed, P.; Neal, S.; Plested, J.S.; Zhu, M.; Cloney-Clark, S.; Zhou, H.; et al. Phase 1-2 trial of a SARS-CoV-2 recombinant spike protein nanoparticle vaccine. N. Engl. J. Med. 2020, 383, 2320-2332. [CrossRef]

18. Heath, P.T.; Galiza, E.P.; Baxter, D.N.; Boffito, M.; Browne, D.; Burns, F.; Chadwick, D.R.; Clark, R.; Cosgrove, C.; Galloway, J.; et al. Safety and Efficacy of NVX-CoV2373 COVID-19 Vaccine. N. Engl. J. Med. 2021, 385, 1172-1183. [CrossRef] [PubMed]

19. Chawla, T.; Khanna, N.; Swaminathan, S. Adenovirus-vectored vaccines. Expert Opin. Ther. Patents 2008, 18, 293-307. [CrossRef] [PubMed]

20. Stephen, S.L.; Montini, E.; Sivanandam, V.G.; Al-Dhalimy, M.; Kestler, H.A.; Finegold, M.; Grompe, M.; Kochanek, S. Chromosomal integration of adenoviral vector DNA in vivo. J. Virol. 2010, 84, 9987-9994. [CrossRef] [PubMed]

21. Knoll, M.D.; Wonodi, C. Oxford-AstraZeneca COVID-19 vaccine efficacy. Lancet 2021, 397, 72-74. [CrossRef]

22. Voysey, M.; Clemens, S.A.C.; Madhi, S.A.; Weckx, L.Y.; Folegatti, P.M.; Aley, P.K.; Angus, B.; Baillie, V.L.; Barnabas, S.L.; Bhorat, Q.E.; et al. Single-dose administration and the influence of the timing of the booster dose on immunogenicity and efficacy of ChAdOx1 nCoV-19 (AZD1222) vaccine: A pooled analysis of four randomised trials. Lancet 2021, 397, 881-891. [CrossRef]

23. Greinacher, A.; Thiele, T.; Warkentin, T.E.; Weisser, K.; Kyrle, P.A.; Eichinger, S. Thrombotic thrombocytopenia after ChAdOx1 nCov-19 vaccination. N. Engl. J. Med. 2021, 384, 2092-2101. [CrossRef]

24. Logunov, D.Y.; Dolzhikova, I.V.; Shcheblyakov, D.V.; Tukhvatulin, A.I.; Zubkova, O.V.; Dzharullaeva, A.S.; Kovyrshina, A.V.; Lubenets, N.L.; Grousova, D.M.; Erokhova, A.S.; et al. Safety and efficacy of an rAd26 and rAd5 vector-based heterologous prime-boost COVID-19 vaccine: An interim analysis of a randomised controlled phase 3 trial in Russia. Lancet 2021, 397, 671-681. [CrossRef]

25. Sadoff, J.; Le Gars, M.; Shukarev, G.; Heerwegh, D.; Truyers, C.; de Groot, A.M.; Stoop, J.; Tete, S.; Van Damme, W.; Leroux-Roels, I.; et al. Interim results of a phase 1-2a trial of Ad26.COV2.S Covid-19 vaccine. N. Engl. J. Med. 2021, 384, 1824-1835. [CrossRef] [PubMed]

26. Pascolo, S. HLA class I transgenic mice: Development, utilisation and improvement. Expert Opin. Biol. Ther. 2005, 5, 919-938. [CrossRef] [PubMed] 
27. Pascolo, S.; Bervas, N.; Ure, J.M.; Smith, A.G.; Lemonnier, F.A.; Pérarnau, B. HLA-A2.1-restricted education and cytolytic activity of CD8(+) T lymphocytes from beta2 microglobulin (beta2m) HLA-A2.1 monochain transgenic H-2Db beta2m double knockout mice. J. Exp. Med. 1997, 185, 2043-2051. [CrossRef] [PubMed]

28. Probst, J.; Brechtel, S.; Scheel, B.; Hoerr, I.; Jung, G.; Rammensee, H.-G.; Pascolo, S. Characterization of the ribonuclease activity on the skin surface. Genet. Vaccines Ther. 2006, 4, 4. [CrossRef]

29. Probst, J.; Weide, B.; Scheel, B.; Pichler, B.J.; Hoerr, I.; Rammensee, H.-G.; Pascolo, S. Spontaneous cellular uptake of exogenous messenger RNA in vivo is nucleic acid-specific, saturable and ion dependent. Gene Ther. 2007, 14, 1175-1180. [CrossRef]

30. Carralot, J.-P.; Probst, J.; Hoerr, I.; Scheel, B.; Teufel, R.; Jung, G.; Rammensee, H.-G.; Pascolo, S. Polarization of immunity induced by direct injection of naked sequence-stabilized mRNA vaccines. Cell. Mol. Life Sci. 2004, 61, 2418-2424. [CrossRef]

31. Scheel, B.; Braedel, S.; Probst, J.; Carralot, J.-P.; Wagner, H.; Schild, H.; Jung, G.; Rammensee, H.-G.; Pascolo, S. Immunostimulating capacities of stabilized RNA molecules. Eur. J. Immunol. 2004, 34, 537-547. [CrossRef]

32. Scheel, B.; Teufel, R.; Probst, J.; Carralot, J.-P.; Geginat, J.; Radsak, M.; Jarrossay, D.; Wagner, H.; Rammensee, H.-G.; Hoerr, I.; et al. Toll-like receptor-dependent activation of several human blood cell types by protamine-condensed mRNA. Eur. J. Immunol. 2005, 35, 1557-1566. [CrossRef]

33. Rittig, S.; Haentschel, M.; Weimer, K.J.; Heine, A.; Muller, M.R.; Brugger, W.; Horger, M.S.; Maksimovic, O.; Stenzl, A.; Hoerr, I.; et al. Intradermal vaccinations with RNA coding for TAA generate CD8+ and CD4+ immune responses and induce clinical benefit in vaccinated patients. Mol. Ther. 2011, 19, 990-999. [CrossRef]

34. Weide, B.; Carralot, J.-P.; Reese, A.; Scheel, B.; Eigentler, T.K.; Hoerr, I.; Rammensee, H.-G.; Garbe, C.; Pascolo, S. Results of the first phase I/II clinical vaccination trial with direct injection of mRNA. J. Immunother. 2008, 31, 180-188. [CrossRef]

35. Weide, B.; Pascolo, S.; Scheel, B.; Derhovanessian, E.; Pflugfelder, A.; Eigentler, T.; Pawelec, G.; Hoerr, I.; Rammensee, H.-G.; Garbe, C. Direct injection of protamine-protected mRNA: Results of a phase 1/2 vaccination trial in metastatic melanoma patients. J. Immunother. 2009, 32, 498-507. [CrossRef]

36. Verbeke, R.; Lentacker, I.; De Smedt, S.C.; Dewitte, H. The dawn of mRNA vaccines: The COVID-19 case. J. Control. Release 2021, 333, 511-520. [CrossRef]

37. Verbeke, R.; Lentacker, I.; De Smedt, S.C.; Dewitte, H. Three decades of messenger RNA vaccine development. Nano Today 2019, 28, 100766. [CrossRef]

38. Henderson, J.M.; Ujita, A.; Hill, E.; Yousif-Rosales, S.; Smith, C.; Ko, N.; McReynolds, T.; Cabral, C.R.; Escamilla-Powers, J.R.; Houston, M.E. Cap 1 messenger RNA Synthesis with Co-transcriptional CleanCap ${ }^{\circledR}$ analog by in vitro transcription. Curr. Protoc. 2021, 1, e39. [CrossRef] [PubMed]

39. Melton, D.A.; Krieg, P.A.; Rebagliati, M.R.; Maniatis, T.; Zinn, K.; Green, M.R. Efficientin vitrosynthesis of biologically active RNA and RNA hybridization probes from plasmids containing a bacteriophage SP6 promoter. Nucleic Acids Res. 1984, 12, 7035-7056. [CrossRef] [PubMed]

40. Scheel, B.; Aulwurm, S.; Probst, J.; Stitz, L.; Hoerr, I.; Rammensee, H.-G.; Weller, M.; Pascolo, S. Therapeutic anti-tumor immunity triggered by injections of immunostimulating single-stranded RNA. Eur. J. Immunol. 2006, 36, 2807-2816. [CrossRef] [PubMed]

41. Pardi, N.; Hogan, M.J.; Porter, F.W.; Weissman, D. mRNA vaccines-A new era in vaccinology. Nat. Rev. Drug Discov. 2018, 17, 261-279. [CrossRef]

42. Kranz, L.M.; Diken, M.; Haas, H.; Kreiter, S.; Loquai, C.; Reuter, K.C.; Meng, M.; Fritz, D.; Vascotto, F.; Hefesha, H.; et al. Systemic RNA delivery to dendritic cells exploits antiviral defence for cancer immunotherapy. Nature 2016, 534, 396-401. [CrossRef]

43. Sahin, U.; Derhovanessian, E.; Miller, M.; Kloke, B.-P.; Simon, P.; Löwer, M.; Bukur, V.; Tadmor, A.D.; Luxemburger, U.; Schrörs, B.; et al. Personalized RNA mutanome vaccines mobilize poly-specific therapeutic immunity against cancer. Nature 2017, 547, 222-226. [CrossRef]

44. Mulligan, M.J.; Lyke, K.E.; Kitchin, N.; Absalon, J.; Gurtman, A.; Lockhart, S.; Neuzil, K.; Raabe, V.; Bailey, R.; Swanson, K.A.; et al. Phase I/II study of COVID-19 RNA vaccine BNT162b1 in adults. Nature 2020, 586, 589-593. [CrossRef] [PubMed]

45. Sahin, U.; Muik, A.; Derhovanessian, E.; Vogler, I.; Kranz, L.M.; Vormehr, M.; Baum, A.; Pascal, K.; Quandt, J.; Maurus, D.; et al. COVID-19 vaccine BNT162b1 elicits human antibody and TH1 T-cell responses. Nature 2020, 586, 594-599. [CrossRef]

46. Walsh, E.E.; Frenck, R.W., Jr.; Falsey, A.R.; Kitchin, N.; Absalon, J.; Gurtman, A.; Lockhart, S.; Neuzil, K.; Mulligan, M.J.; Bailey, R.; et al. Safety and immunogenicity of two RNA-based COVID-19 vaccine candidates. N. Engl. J. Med. 2020, 383, 2439-2450. [CrossRef] [PubMed]

47. van Doremalen, N.; Fischer, R.J.; Schulz, J.E.; Holbrook, M.G.; Smith, B.J.; Lovaglio, J.; Petsch, B.; Munster, V.J. Immunogenicity of low-dose prime-boost vaccination of mRNA vaccine CV07050101 in non-human primates. Viruses 2021, 13, 1645. [CrossRef] [PubMed]

48. Baden, L.R.; El Sahly, H.M.; Essink, B.; Kotloff, K.; Frey, S.; Novak, R.; Diemert, D.; Spector, S.A.; Rouphael, N.; Creech, C.B.; et al. Efficacy and safety of the mRNA-1273 SARS-CoV-2 vaccine. N. Engl. J. Med. 2021, 384, 403-416. [CrossRef]

49. Karikó, K.; Buckstein, M.; Ni, H.; Weissman, D. Suppression of RNA Recognition by Toll-like receptors: The impact of nucleoside modification and the evolutionary origin of RNA. Immunity 2005, 23, 165-175. [CrossRef]

50. Pardi, N.; Secreto, A.J.; Shan, X.; Debonera, F.; Glover, J.; Yi, Y.; Muramatsu, H.; Ni, H.; Mui, B.L.; Tam, Y.K.; et al. Administration of nucleoside-modified mRNA encoding broadly neutralizing antibody protects humanized mice from HIV-1 challenge. Nat. Commun. 2017, 8, 14630. [CrossRef] 
51. Honke, N.; Shaabani, N.; Cadeddu, G.; Sorg, U.R.; Zhang, D.-E.; Trilling, M.; Klingel, K.; Sauter, M.; Kandolf, R.; Gailus, N.; et al. Enforced viral replication activates adaptive immunity and is essential for the control of a cytopathic virus. Nat. Immunol. 2011, 13, 51-57. [CrossRef]

52. Wang, Z.; Schmidt, F.; Weisblum, Y.; Muecksch, F.; Barnes, C.O.; Finkin, S.; Schaefer-Babajew, D.; Cipolla, M.; Gaebler, C.; Lieberman, J.A.; et al. mRNA vaccine-elicited antibodies to SARS-CoV-2 and circulating variants. Nat. Cell Biol. 2021, 592, 616-622. [CrossRef]

53. Dagan, N.; Barda, N.; Kepten, E.; Miron, O.; Perchik, S.; Katz, M.A.; Hernán, M.A.; Lipsitch, M.; Reis, B.; Balicer, R.D. BNT162b2 mRNA COVID-19 vaccine in a nationwide mass vaccination setting. N. Engl. J. Med. 2021, 384, 1412-1423. [CrossRef] [PubMed]

54. Naaber, P.; Tserel, L.; Kangro, K.; Sepp, E.; Jürjenson, V.; Adamson, A.; Haljasmägi, L.; Rumm, A.P.; Maruste, R.; Kärner, J.; et al. Dynamics of antibody response to BNT162b2 vaccine after six months: A longitudinal prospective study. Lancet Reg. Health-Eur. 2021, 100208, in press. [CrossRef] [PubMed]

55. Haas, E.J.; McLaughlin, J.M.; Khan, F.; Angulo, F.J.; Anis, E.; Lipsitch, M.; Singer, S.R.; Mircus, G.; Brooks, N.; Smaja, M.; et al. Infections, hospitalisations, and deaths averted via a nationwide vaccination campaign using the Pfizer-BioNTech BNT162b2 mRNA COVID-19 vaccine in Israel: A retrospective surveillance study. Lancet Infect. Dis. 2021, 10, online ahead of print. [CrossRef] 